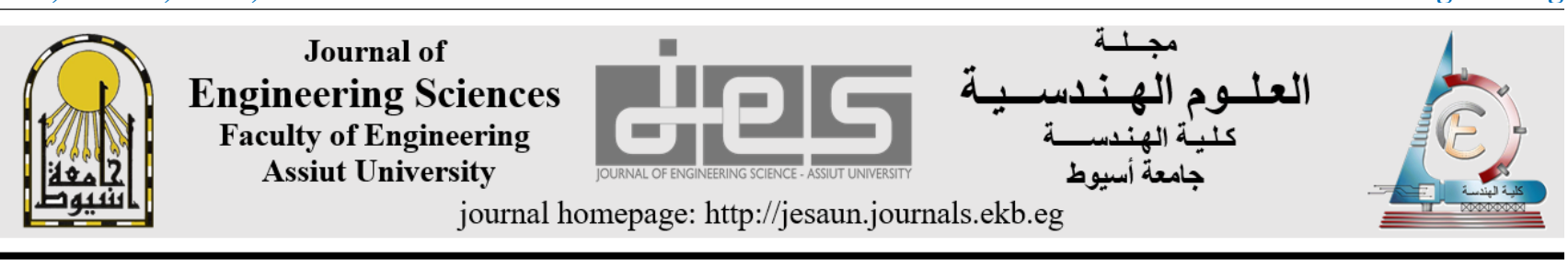

\title{
Guidelines to estimate Earthquake Loads on Buildings in Slum Areas
}

\author{
Received 25 November 2021; Revised 3 January 2022; Accepted 5 January 2022
}

\begin{abstract}
Ahmed Hashad ${ }^{1}$
Emad Helal $^{2}$
\end{abstract}

\section{Keywords}

Dynamic analysis, Building assessment, Seismic design, Structural evaluation

\begin{abstract}
Slums and non-engineering buildings are scattered in Egyptian cities. Here comes the challenge facing the state, including the engineering bodies, to determine the danger level to the residents' lives, and to develop solutions and priorities for facing risks including earthquakes. The large size of slums necessitates the development of a simplified way for classifying structures in terms of their seismic resistance. This research proposes a simplified method to estimate the earthquake loads to be used for estimating the ability of such buildings to withstand the main and seismic loads, allowing the determination of the initial degree of danger on its condition. The proposed guideline ignores the effect of participation of all columns in resisting earthquake loads, especially in the absence of lateral stiffness members, which is the general condition of slums and focuses on the external columns only that are the most exposed to the seismic load. Also, this method considers only the resulting seismic vertical reactions. The validity of the proposed method was tested experimentally and analytically, while its accuracy was verified through a field study by comparing the results of its application on two buildings in Sharika, Egypt. Numerical models for these buildings were built to determine their resistance under seismic loads. The study concluded how to predict the risks affecting such buildings using a simple process. This could be used to establish controls to replanning the buildings of existing slum cities to ensure the safety or at least reduce the risk of collapses against moderate earthquakes.
\end{abstract}

\section{Introduction}

The increase in land prices has contributed to the increase in the prices of housing units, especially in the new cities, which prompted a lot of investment in the slums. Many have been motivated by greed in the construction of residential towers ranging from ten to twenty stories in all the governorates of Egypt, especially in the Delta and Alexandria. These slum buildings are out of Egyptian construction standards at the level of design or implementation work. This issue leads to

\footnotetext{
${ }^{1}$ Professor, Construction Research Institute, National Water Research Center, Egypt.

${ }^{2}$ Assistant Professor, October University for Modern Sciences and Arts (MSA), Egypt.
} 
the uncertainty of the safety for these buildings. This problem is evident in the case of facing disaster risks in general, especially natural disasters due to the size of their impact. Fahmy and Hamad (2018) presented a study discussing the structural evaluation of existing non-engineering residential buildings under vertical and lateral loads based on Egyptian codes of practice. They have performed a case study in a village called Strict in Munafaya governorate, Egypt. They concluded that the frame with infill wall significantly enhances the structure to resist lateral loads from earthquake, so the existing structure with infill wall can resist gravity and lateral loads safely based on the ECP provision. Badawy et al. (2014) proposed estimation scenarios for earthquake risk assessment of Alexandria, Egypt. They concluded that buildings within informal settlements are mostly made of masonry, which is more vulnerable to earthquake risks not only in Alexandria but also throughout the whole Egyptian lands. They recommended that these areas need to be initiated in re-planning to achieve a future reduction of earthquake risks. Sabahi and Nazif (2012) proposed a methodology for seismic risk evaluation of existing reinforced school buildings which have the priority for seismic risk evaluation because of their high public occupancy and they may serve as emergency shelters after any disaster. Their methodology is based mainly on questionnaire forms and a computer program to execute this methodology quickly and with reasonable accuracy based on scientific fundamentals. Their research showed a good agreement with the state of damage of the school buildings, so it can be applied by the official authorities for preparing a prioritization plan of the structural safety of all existing reinforced concrete school buildings in Egypt. El-Betar (2018) studied seismic evaluation of existing R.C. buildings in Egypt that were designed to resist gravity loads only (GLD). Their proposed procedure consists of a rapid visual inspection procedure that is convenient to the Egyptian conditions. For buildings that did not achieve the seismic resistance in rapid inspection, a multi-phase procedure is used. Their seismic procedure includes three levels of evaluation depending on the conditions and requirements of each case. Their study concluded that the school buildings designed according to Egyptian code have a high capacity to resist earthquakes compared to GLD buildings. Malaterre-Barthes (2016) studied the informal housing settlements in Egypt that were built without permits, mostly on former agrarian land. This phenomenon has been accelerated after 2011 revolution. Marked by ongoing construction, these settlements mainly follow property lines and the contours of agricultural fields, which are narrow strips of land of 100-300 meters long and 6-17 meters wide, bordered by irrigation canals. Buildings were, at first, singlehouse types and multistorey apartment buildings its area ranges between $125 \mathrm{~m}^{2}$ to $190 \mathrm{~m}^{2}$. For construction that has two or three 60-square-meter apartments per floor, each with two bedrooms and a living room. Abdo and Hamada (2017) introduced a set of mechanisms for developing informal settlements according to the principles of sustainable development according to the conditions of the urban, social, and economic environment to ensure that development projects are successful in achieving the desired urban sustainability. Hashad (2016) introduces a simple methodology to estimate the internal dynamic forces that affected on a simple beam because of exposure to vibrations.

The objectives of this study are performing a proposal for a simplified mathematical formula to predict the additional seismic columns' loads for a traditional skeleton R.C. building, which provides a direct simple guide to predict the seismic risks. The validity of the proposed formula has been tested experimentally through performing dynamic tests on R.C. beam samples, and analytically through numerical analysis for framing models comparing the results to the application of Egyptian Code of Practice "ECP" for seismic loads. The proposed procedure was also verified via performing a field study on buildings in one of the typical slum areas which was one of the Egyptian country villages in the province of Sharika governorate. Some data were collected through the contractors leading this kind of business and field investigation and surveying works were carried out to determine section dimensions and reinforcing steel quantities for various structural elements. Schmidt hammer was used in predicting the homogeneity of the resistance of reinforced concrete. 


\section{Proposed Method for Seismic Force Estimation}

Simple formula has been suggested to estimate the seismic force affecting a traditional skeleton building by considering the resultant of seismic forces affecting the building as a horizontal concentrated force applied at $(2 / 3)$ of its height. Figure (1) displays the effect of earthquake force on a building. The following section explains the derivation of the proposed method.

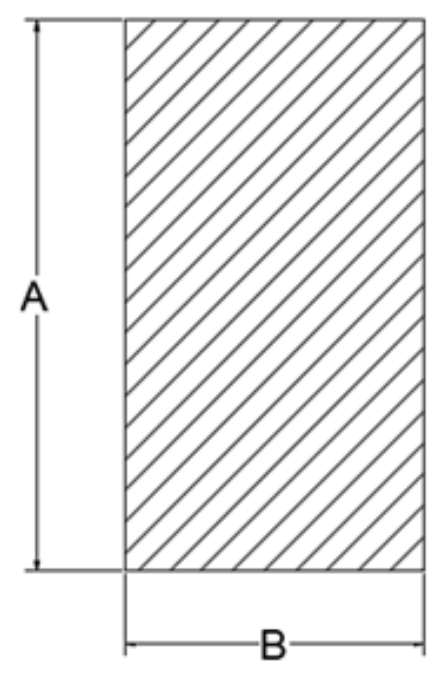

PLAN

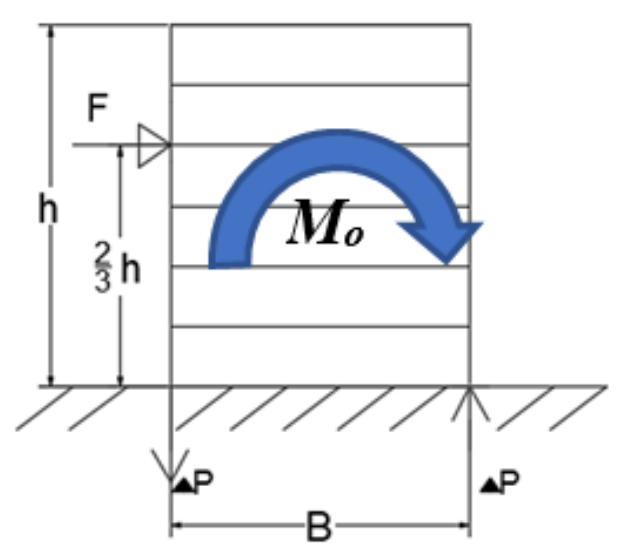

ELEV.

Fig (1) Traditional building skeleton under the influence of seismic load

$\mathrm{M}_{\mathrm{o}}=F \times\left(\frac{2}{3} h\right)$

Where.

$$
\mathrm{F}=\mathrm{m}_{\mathrm{t}} \times \mathrm{a}
$$

$$
m=\frac{A \times B \times w}{g} \quad, \quad \mathrm{~m}_{\mathrm{t}}=\frac{A \times B \times w \times n}{g}
$$

$\Delta P=\frac{M o}{R}=\frac{F\left(\frac{2}{3} h\right)}{R} \quad, \quad \Delta P=\frac{2(m t)(a)(h)}{3 B}$ substituting from Eqs. $(1,2)$

$$
\Delta P=\frac{2(a)(h)}{3 B} \times \frac{A \times B \times w \times n}{g}, \text { Use } n=\frac{(h)}{3}
$$$$
\Delta P=\frac{2(a)(h)}{3 B} \times \frac{A \times B \times w \times h}{3 g} \rightarrow \Delta P=\frac{2 a \times h^{2} \times A \times w}{9 g} \rightarrow \Delta P=\left(\frac{2 a}{9 g}\right)\left(A \times w \times h^{2}\right)
$$

$$
\Delta P=\left(\frac{2 a}{2 g} \times w\right) \times\left(A \times h^{2}\right)
$$

where;

$\mathrm{A}, \mathrm{B}, \mathrm{h}=$ Building dimensions in meters (Length, Width and Height respectively)

$\mathrm{n} \quad=$ No. of Stories $\approx \mathrm{h} / 3$; (average story height $\approx 3.0 \mathrm{~m}$ )

$\mathrm{w} / \mathrm{m}^{2}=$ Intensity of Total Equivalent Floor Loads $/ \mathrm{m}^{2}$; (ECP); (D.L + 0.25 L. L)

$\Delta \mathrm{P} \quad=$ Additional Resulting Vertical Seismic Load on the External Columns

$\mathrm{m} \quad=$ Mass of one Story

$-\mathrm{mt}=$ Total Mass of the Building $=\mathrm{m} \times \mathrm{n}$ 


$$
\begin{array}{lll}
\mathrm{F} & =\text { Total Seismic Force } & -\mathrm{M}_{0}=\text { Total Resulting Seismic Moment } \\
\mathrm{g} & =\text { Gravity Acceleration }\left(9.81 \mathrm{~m} / \mathrm{s}^{2}\right) & -\mathrm{a}=\text { Zoning Seismic Acceleration }
\end{array}
$$

As shown from Eq. (3), where the first bracket $\left(\frac{2 \mathrm{a}}{9 \mathrm{~g}} \times \mathrm{w}\right)$ could be considered almost constant for same seismic zone and average equivalent intensity floor loads, the increase in external columns' loads due to seismic effect $(\Delta \mathrm{P})$ is proportional to building length " $\mathrm{A}$ " times square of building height " $\mathrm{h}$ ".

\section{Experimental Work}

The purpose of the experimental work is clarifying that any structure system subjected to dynamic load, regardless its dynamic properties, a static load equivalent to the effect of the dynamic load could be estimated if the value of the acceleration of its vibration response was determined, which is the proposed guideline of the present research is based on, but with using the acceleration value considered in the Egyptian code for loads. The suggested method depends on calculation of the general equilibrium of a building exposed to lateral forces because of an earthquake. The seismic forces were calculated because of multiplying the resultant mass of the building by the value of the expected seismic acceleration. Dynamic test was carried out on simple beam to make sure of the applicability of the proposed method. The test was designed based on applying $2^{\text {nd }}$ Newton law by using the acceleration measurement at specific points and the estimated concentrated masses at these points to estimate the forces affecting the structure. Simply supported reinforced concrete beam with $360 \mathrm{~cm}$ span and cross section $10 \mathrm{~cm}$ width $\times 20 \mathrm{~cm}$ depth was excited using an impact hammer. The beam acceleration and strain responses were measured using three accelerometers distributed along its span and a strain gauge sensor fixed at midpoint of the beam top surface. Figure 2 shows the test setup and beam cross section. The dynamic test was carried out 5 times for the purpose of test accuracy.

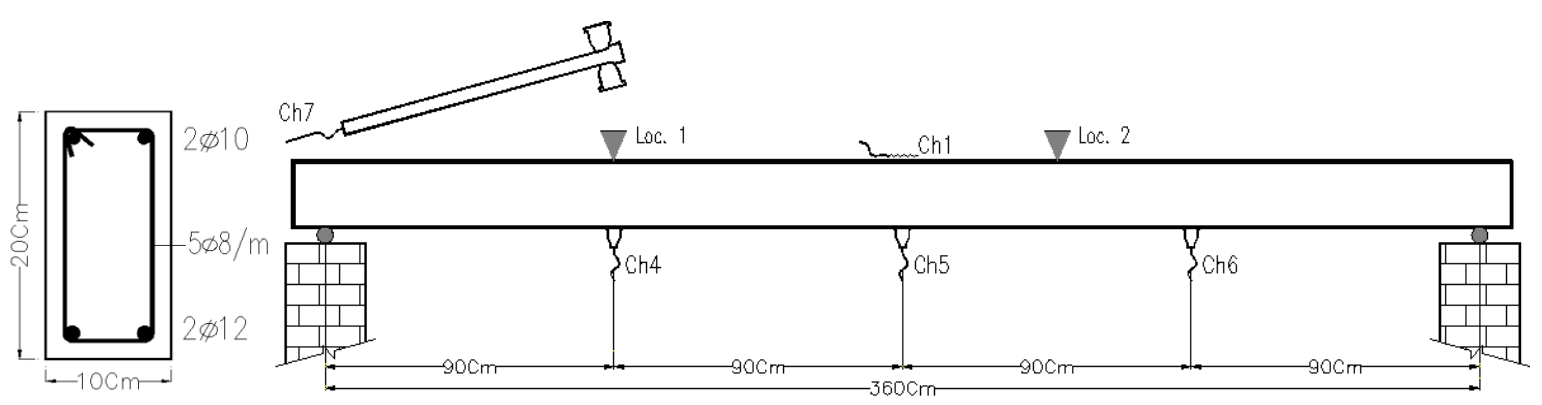

Fig 2 Test setup and beam cross section configuration

Figure 3 shows the photos of the used sensors and the tested beam with its test setup. The records were subjected to signal processing to enhance the reading accuracy and minimizing the effect of signal noises and zero readings. Figure 4 displays samples of the acceleration, impact force and strain time records.
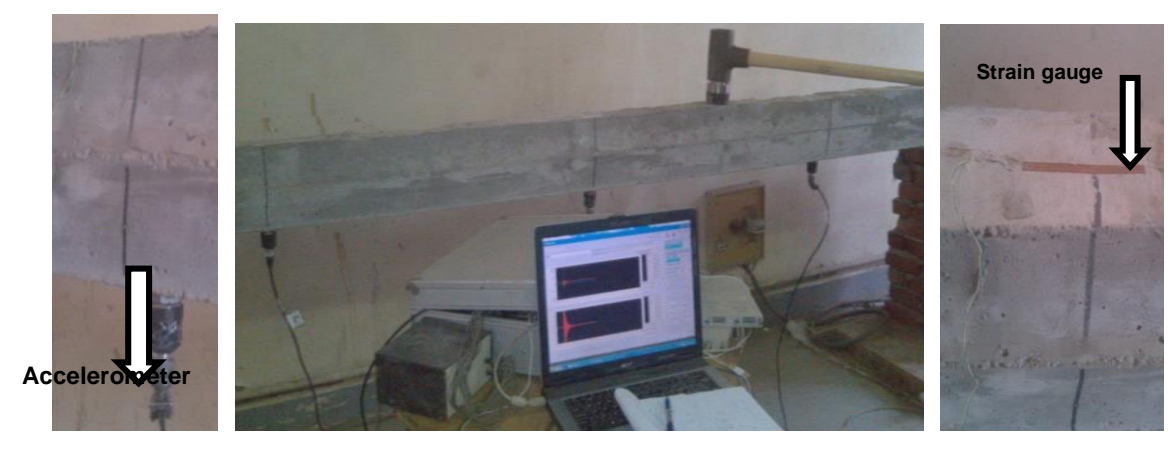
Fig 3 Test setup showing accelerometer and the strain gauge sensors

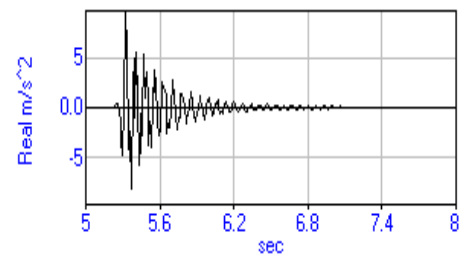

a. Acceleration

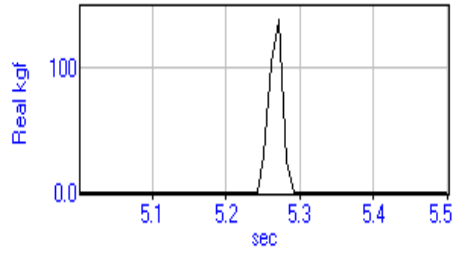

b. Impact Force

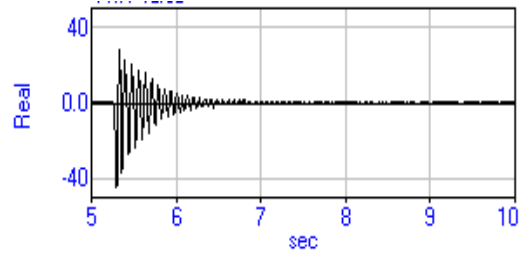

c. Strain

Fig 4 Samples of different measurements time histories

\section{Experimental Results}

The beam midpoint strain due to excitation forces was calculated using the proposed method. The calculated strain was based on estimating the forces that represents the effect of beam mass motion. Three concentrated masses were used to model the beam distributed mass and were concentrated at the location of the measured accelerations as displayed in Figure 5.

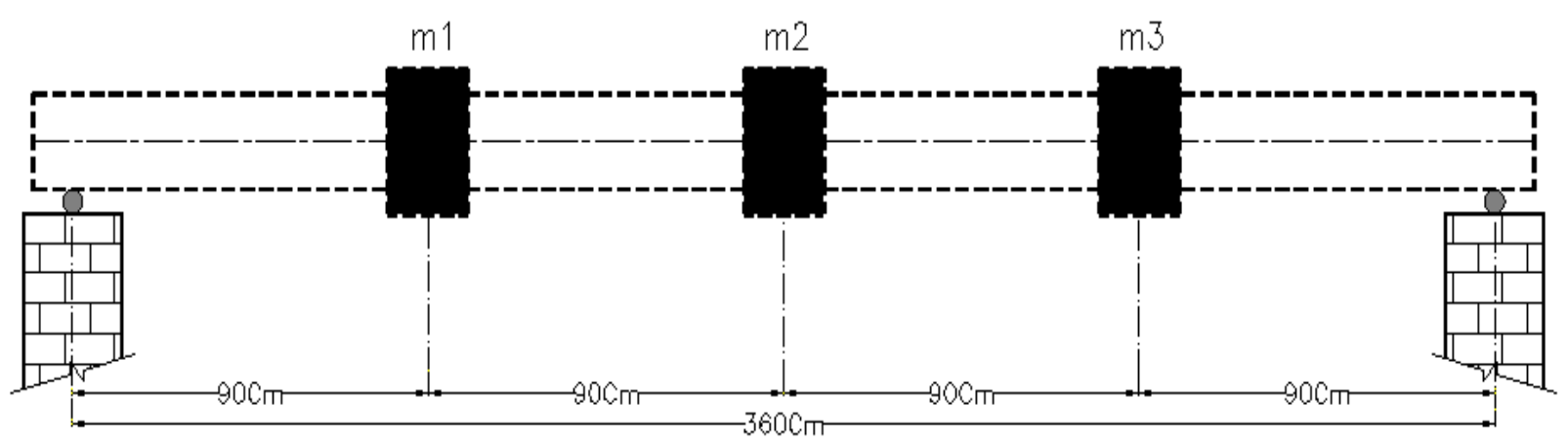

Fig5 The beam modelled concentrated masses

The beam own weight for each meter length was estimated using its cross-section dimensions with assumed density equal to $2.50 \mathrm{t} / \mathrm{m}^{3}$. The beam distributed mass:

$$
\begin{aligned}
& \mathrm{m}_{\mathrm{L}}=\frac{0.10 \times 0.20 \times 2.5}{9.81}=0.0051 \text { ton (mass) } \\
& \mathrm{m}_{1}=\mathrm{m}_{2}=\mathrm{m}_{3}=0.0051 \times 1000 \times 0.90=4.60 \mathrm{~K}_{\mathrm{g}} \text { (mass) }
\end{aligned}
$$

The force that represents the mass motions was calculated using the Newton's $2^{\text {nd }}$ law as previously explained by multiplying the mass value with the measured acceleration value at this point. Then, these forces were applied on the beam at each mass point as a concentrated force. Figure 6 displays the concentrated forces which represent the mass motion effect.

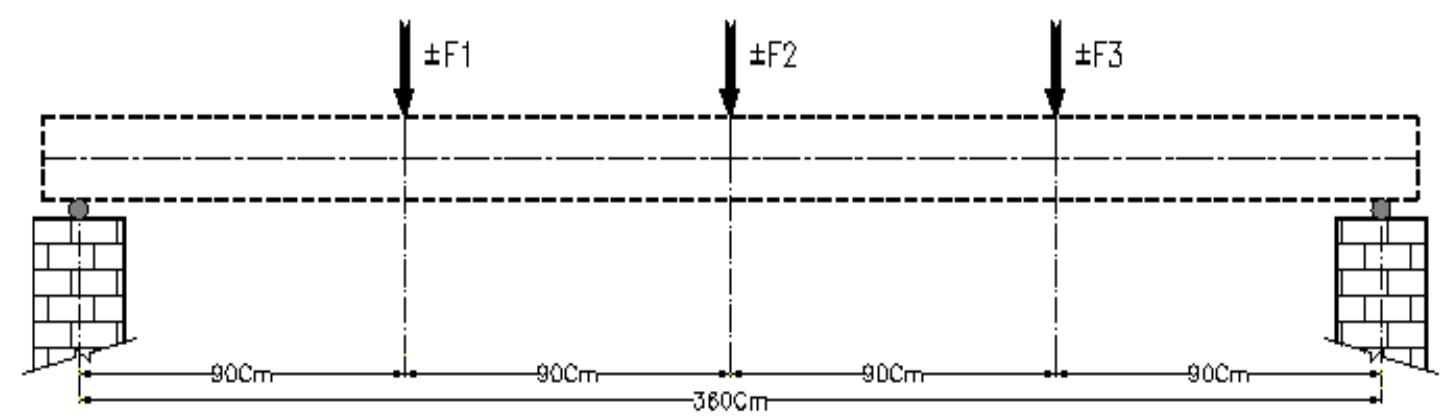

Fig 6 Concentrated forces represent the masses motion effects 
To validate the methodology, the resulting strain was compared with the measured strain. The strain value at the midpoint was calculated using the following formula:

$$
\begin{gathered}
f=E \cdot \varepsilon \\
f=\frac{M y}{I}
\end{gathered}
$$

where;

f: Normal stresses due to moment, E: Elastic modulus, $\mathcal{E}$ : Strain, M: Bending moment,

I: Moment of Inertia, and y: is the edge distance measured from neutral axis.

From Eqs. ( $4 \& 5)$; the strain value due to normal stress induced by moment:

$$
\varepsilon=\frac{\mathrm{My}}{\mathrm{EI}}
$$

The modulus of elasticity was calculated using the Egyptian Code for Concrete Structures "ECP 203 (2017)" and the value of compressive strength of the used concrete was determined from concrete mix quality control tests to be $180 \mathrm{~kg} / \mathrm{cm}^{2}$. The moment value was calculated at the midpoint by:

$$
\mathrm{M}=\mathrm{R}_{\mathrm{L}} \times 180-\mathrm{F}_{1} \times 90 \quad \mathrm{~kg} . \mathrm{cm}
$$

where;

M: Moment force

$\mathrm{R}_{\mathrm{L}}$ : Vertical Reaction at left support

$\mathrm{F}_{1}$ : concentrated force

$$
\mathrm{R}_{\mathrm{L}}=\frac{\mathrm{F}_{1} \times 270+\mathrm{F}_{\mathrm{g}} \times 180+\mathrm{F}_{\mathrm{g}} \times 90}{360} \quad \mathrm{~kg}
$$

where;

$$
\begin{aligned}
\mathrm{F}_{1}=\mathrm{m}_{1} \times \mathrm{a}_{1} \quad, \quad \mathrm{~F}_{2}=\mathrm{m}_{2} \times \mathrm{a}_{2} \& \quad \mathrm{~F}_{3}=\mathrm{m}_{3} \times \mathrm{a}_{3} \\
\mathrm{M}=45 \times \mathrm{m}\left(2 \mathrm{a}_{2}+3 \mathrm{a}_{3}-\mathrm{a}_{1}\right) \quad \mathrm{kg} . \mathrm{cm}
\end{aligned}
$$

$\mathrm{a}_{1}, \mathrm{a}_{2} \& \mathrm{a}_{3}$ are the acceleration values at these points and the three values that were measured and recorded experimentally.

The relation between the calculated strain and the measured strain for different tests was plotted and displayed in Figure 7. The results obtained from the experimental studies were evaluated using correlation technique. The correlation between the measured strain and the calculated one was determined taken into considerations points after shock only. The average correlation degree was determined for the five tests, and it was about (0.90) as shown in Figure 7. 

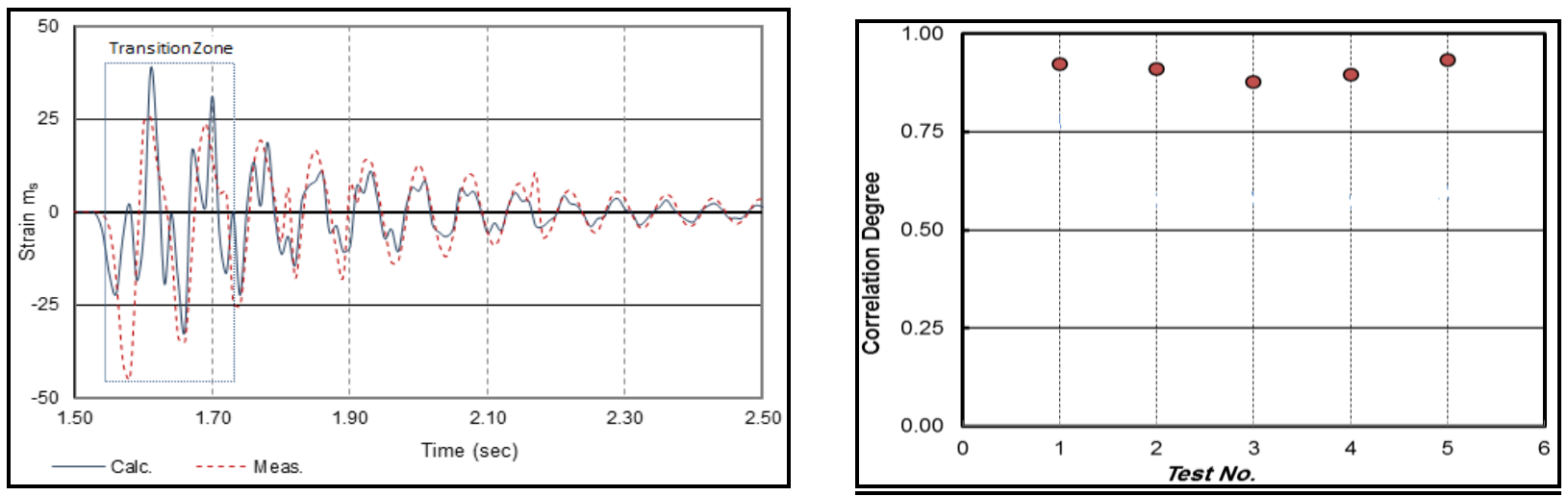

Fig 7 Measured versus calculated strain response and their correlation degree

\section{Comparison between Proposed Formula \& ECP Seismic Loads}

Four 2D Numerical models of typical buildings consisting of a 4-7 number of stories were represented to test the extent to which the results of the proposed method are like the results of applying the Egyptian code for earthquake loads "ECP 201 (2012)". The structural system of the typical building consists of frames with multiple span and floors. Figure 8 shows the 4-stories building model. For a rational comparison, the following assumptions and items have been coordinated with proposed concept:

- S (soil type factor) $=1$; as it is not considered in the proposed formula

- $\gamma$ (Importance factor) $=1$

- $\quad \eta$ (Damping correction factor) $=1$; R.C. Buildings

- $\quad \mathrm{ag}_{\mathrm{g}}($ Seismic zone $)=0.125 \mathrm{~g} ;($ Zone 2$) ;$ thus; $\mathrm{T}_{\mathrm{B}}=0.05, \mathrm{~T}_{\mathrm{C}}=0.25$ and $\mathrm{T}_{\mathrm{D}}=1.2$

- $\quad$ Response Spec. = Type (1); that used generally for all Egyptian regions

$\mathrm{R}=$ Modification factor for Structural System Ductility; (for the considered str. system $\mathrm{R}=5$ )

- $\quad W=$ total weight for the structure (D.L + 0.25 L. L) for case of residential building; assuming total equivalent uniform floor loads (including own weight of beams) $\mathrm{W}=0.85 \mathrm{t} / \mathrm{m}^{2}$; thus; for numerical Model (1).

$\mathrm{W}$ (for one Bay $4.0 \mathrm{~m}$ "one Frame") $=0.85 \times 4 \times 13 \times 4$ Floors $=176.8 \mathrm{t}$; thus.

$\mathrm{F}_{\mathrm{b}}=0.369 \times 0.85 \times 176.8 / 9.81=5.65 \mathrm{t}$, where the correction factor " $\lambda$ " $=0.85$, as the fundamental period of this model " $\mathrm{T}_{\mathrm{o}}$ " $=0.42 \mathrm{sec} .<2 \mathrm{~T}_{\mathrm{c}}(0.5 \mathrm{sec}$.). The fundamental periods for all models are presented in Table (1).

The seismic base force " $\mathrm{F}_{\mathrm{b}}$ " was distributed to the building stories as: -

$1^{\text {st }}$ Level $(\mathrm{F} 1)=0.66 \mathrm{t}-2$ nd Level $(\mathrm{F} 2)=1.17 \mathrm{t}-3 \mathrm{rd}$ Level $(\mathrm{F} 3)=1.67 \mathrm{t}-4$ th Level $(\mathrm{F} 4)=2.16 \mathrm{t}$

Applying these lateral forces to the Numerical Framing Model (1) that is shown below, the resulting additional seismic load on Exterior Frame Column; $\Delta \mathrm{P}=4.98 \mathrm{t}$. 

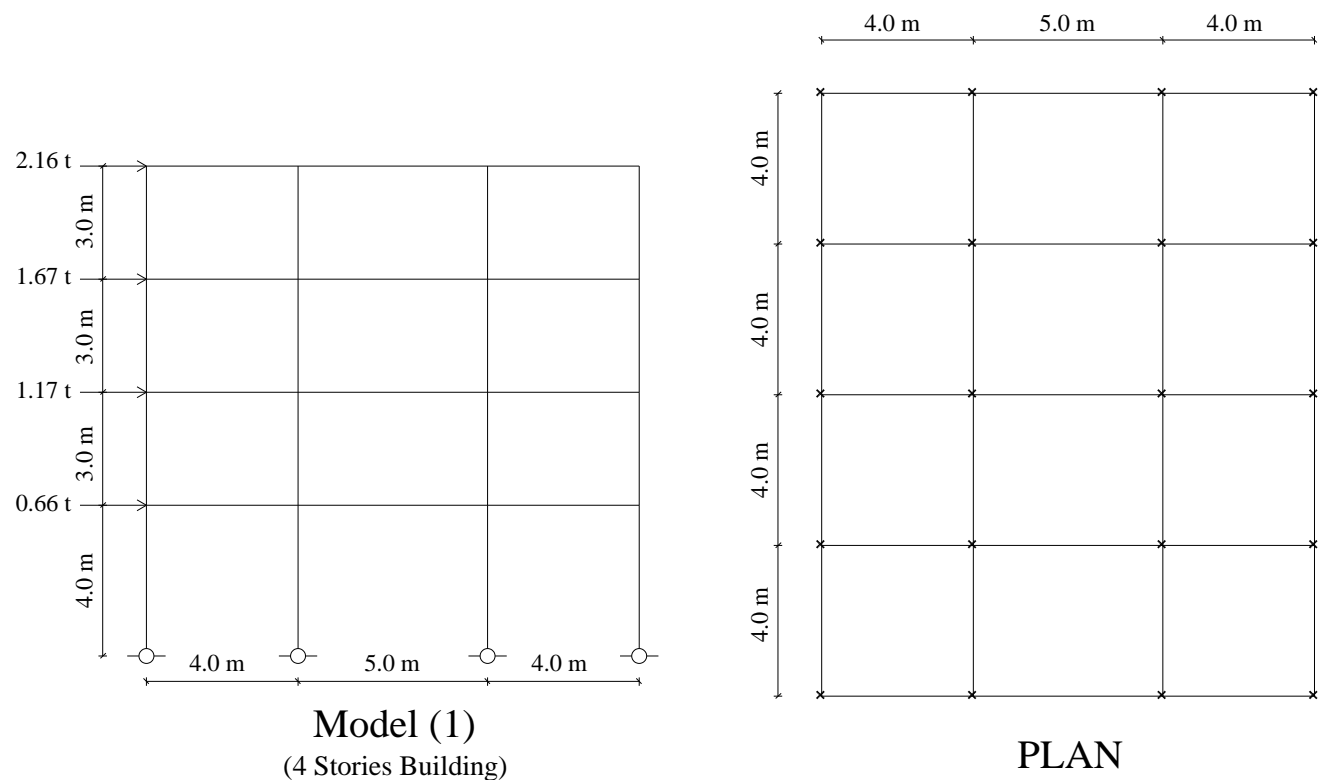

Fig 8 Model (1) structural system

According to ECP, these resulting seismic loads are Ultimate Loads; thus, for working analysis (for comparison with the proposed concept), seismic load should be reduced dividing it by a value (1.4); thus; the coded value $\Delta \mathrm{P}$ is reduced as follows:

$\Delta \mathrm{P}=4.98 / 1.4=3.55 \mathrm{t}$. Applying the Proposed Formula for same building and the considered assumptions.

$$
\begin{gathered}
\Delta P=\left(\frac{2 a}{9 g} \times w\right) \times\left(A \times h^{2}\right) \\
\Delta \mathrm{P}=(2 \times 0.125 \times 0.85) \times\left(4 \times 13^{2}\right) / 9=15.96 \mathrm{t},
\end{gathered}
$$

it is obvious the large difference between application of the two concepts, the main reason is considering factor $(\mathrm{R})$ in the ECP Equation, thus, it should be considered to the proposed formula by dividing the final Eq. on (R). For the considered structural system, $\mathrm{R}=5$.

$\Delta \mathrm{P}=15.96 / 5=3.19 \mathrm{t}$. Thus, the difference between the two concepts is $(-10.1 \%)$. Performing same comparisons for the other models $(5,6,7$ stories), the results are shown in Table (1).

Table (1) Comparison seismic loads of numerical models \& proposed method

\begin{tabular}{|c|c|c|c|c|}
\hline \multirow{2}{*}{ Cases } & \multirow{2}{*}{$\begin{array}{c}\text { Fund. } \\
\text { Period } \\
\text { (T) }\end{array}$} & \multicolumn{3}{|c|}{ Additional seismic load on Exterior Frame Columns $\mathbf{\Delta P}$ (ton) } \\
\cline { 3 - 5 } & $\begin{array}{c}\text { Num. Results using Equiv. } \\
\text { Seism. Lds (ECP) }\end{array}$ & $\begin{array}{c}\text { Simplified Proposed } \\
\text { Formula }\end{array}$ & \% Difference \\
\hline Model (1): 4 - Stories & 0.42 & 3.55 & 3.19 & $-10.1 \%$ \\
\hline Model (2): 5 - Stories & 0.45 & 4.71 & 4.84 & $+2.7 \%$ \\
\hline Model (3): 6 - Stories & 0.47 & 6.34 & 6.82 & $+7.6 \%$ \\
\hline Model (4): 7 - Stories & 0.54 & 8.26 & 9.14 & $+10.7 \%$ \\
\hline
\end{tabular}

As shown, the difference ratio between the two methods became more reasonable, and it increases by increasing the building height. Also, the average floor height applied in performing the proposed formula is assumed $=3.0 \mathrm{~m}$, while in the numerical model, the $1^{\text {st }}$ floor height is assumed $4.0 \mathrm{~m}$. Additionally, the number of frames bays, its span values, in addition to the relative stiffness between building beams and columns are not considered in the proposed formula. The method is 
with acceptable difference for buildings with 4- $\vee$ stories where the value of the difference range is $\pm 10 \%$ than the analytical method. The proposed guideline could be simplified and taking into consideration only the negative difference (unsafe side) as a correction factor (1.10) as follows:

$$
\Delta P=\left(\frac{2 a}{9 g} \times w\right) \times\left(A \times h^{2}\right) \times 1.10
$$

Substitute the following values in the above equation

$\mathrm{a}=0.125 \mathrm{~g} \quad \mathrm{w}=0.85 \mathrm{t} / \mathrm{m}^{2} \quad \mathrm{~A}=4.0 \mathrm{~m} \quad$ Correction factor $=1.10$

So, the proposed formula is: -

$$
\Delta P=\left(\frac{h^{2}}{10}\right)
$$

Therefore, for buildings with 4-7 stories in slum areas that did not apply the seismic design precautions, Eq. (10) could be used to estimate the value of the additional seismic load for one of the external columns. This simplified equation is not considering the coded factor $(\mathrm{R})$ that is more convenient for the construction types considered in this study.

\section{Verification Method}

Field study was carried out on two existing non-engineered residential buildings in Hehia City; Sharika governorate, Egypt. This field study was based on the cooperation of the owners of buildings in one of the typical slum areas that represent the most prevalent buildings in terms of the number of floors and area. Surveying and questionnaires works were conducted to prepare as built drawings including beams, columns and foundation dimensions and reinforcement data.
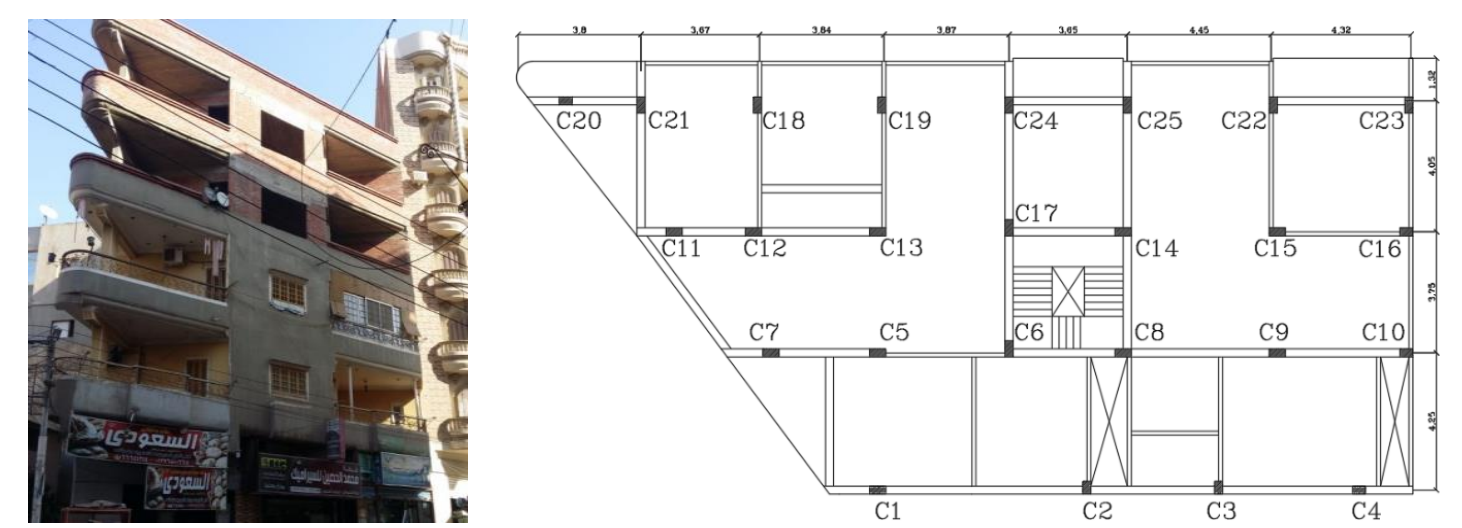

Fig 9 Building (I) photo and it's as built typical floor structural system

Building (I) is a residential building consists of ground floor and four typical floors as shown in Figure 9. The heights of the ground and typical floor are 4.0 and $3.0 \mathrm{~m}$ respectively. The building is reinforced concrete skeleton. Foundations are isolated footings with thickness $60 \mathrm{~cm}$ rested on plain concrete with thickness $40 \mathrm{~cm}$. The internal footings with dimensions $2.50 \times 2.00 \mathrm{~m}$, while external footings are with dimensions $1.50 \times 1.20 \mathrm{~m}$. All footings are reinforced by $6 \Phi 12 / \mathrm{m}$ in both directions. The footings relate to smells have concrete dimensions $25 \times 60 \mathrm{~cm}$ reinforced with $3 \Phi 12$ top, and bottom and stirrups $6 \varnothing 8 / \mathrm{m}$. Floor system is solid slabs with projected beams. Concrete slab thickness is $15 \mathrm{Cm}$ with mesh reinforcement $7 \varnothing 10 / \mathrm{m}$. Column's data are displayed in Table (2) while beams data are shown in Table (3). 
Table (2) Columns dimensions and reinforcements for building (I)

\begin{tabular}{|c|c|c|c|c|c|c|}
\hline \multirow{2}{*}{ Model } & \multicolumn{2}{|c|}{ Ground Floor } & \multicolumn{2}{c|}{ Typical Floors } & \multirow{2}{*}{$\begin{array}{c}\text { Stirrups } \\
\text { /m }\end{array}$} & \multirow{2}{*}{ Notes } \\
\cline { 2 - 5 } & Sec. $(\mathbf{c m})$ & Rfts & Sec. $(\mathbf{c m})$ & Rfts & \multirow{2}{*}{6 Interior } \\
\hline Col. 1 & $30 \times 50$ & $\begin{array}{l}4 \Phi 16+ \\
4 \Phi 12\end{array}$ & $25 \times 50$ & $8 \Phi 12$ & 68 & External \\
\hline Col. 2 & $25 \times 40$ & $6 \Phi 12$ & $25 \times 40$ & $6 \Phi 12$ & $6 \varnothing 8$ & \multirow{2}{*}{} \\
\hline
\end{tabular}

Table (3) Beams dimensions and reinforcements for building (I)

\begin{tabular}{|c|c|c|c|c|}
\hline \multirow{2}{*}{ Model } & \multirow{2}{*}{ Sec. $(\mathbf{c m})$} & \multicolumn{2}{|c|}{ Reinforcement } & \multirow{2}{*}{$\begin{array}{c}\text { Stirrups } \\
\text { /m }\end{array}$} \\
\cline { 3 - 4 } & & Bottom & Top & $6 \varnothing 8$ \\
\hline B1 & $12 \times 65$ & $2 \Phi 12$ & $2 \Phi 12$ & $6 \varnothing 12$ \\
\hline
\end{tabular}
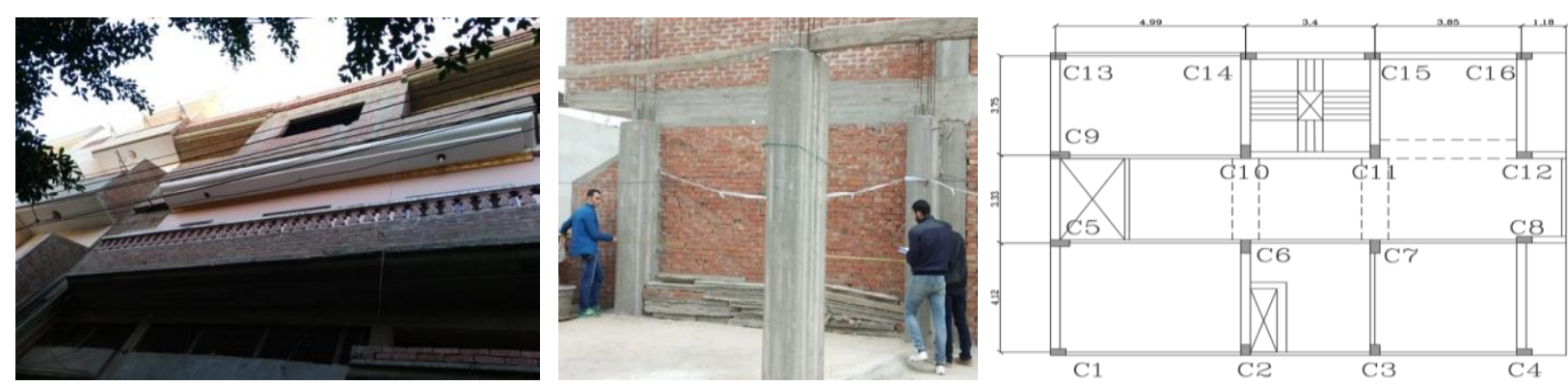

Fig 10 Building (II) Photo during field study and showing its floor structural system

Building (II) is a residential building consists of ground floor and three typical floors. There is an almost complete match between Building (I) and Building (II) in the construction system, the floor heights, and foundations, with some differences, they were monitored through questionnaires, where the dimensions of internal footing are $2.20 \times 1.80 \mathrm{~m}$ and slab thickness are $20 \mathrm{~cm}$ with only bottom mesh $7 \varnothing 10 / \mathrm{m}$. Figure 10 shows a photo of the building and a photo during the Schmidt hammer test as well as the as built drawings. Table (4) displays the building columns data, while building beams dimensions and reinforcements are shown in Table (5).

Table (4) Columns dimensions and reinforcements for building (II)

\begin{tabular}{|c|c|c|c|c|c|c|}
\hline \multirow{2}{*}{ Model } & \multicolumn{2}{|c|}{ Ground Floor } & \multicolumn{2}{c|}{ Typical Floors } & \multirow{2}{*}{$\begin{array}{c}\text { Stirrups } \\
\text { /m }\end{array}$} & \multirow{2}{*}{ Notes } \\
\cline { 2 - 5 } & Sec. $(\mathbf{c m})$ & Rfts & Sec. $(\mathbf{c m})$ & Rfts & & \\
\hline Col. 1 & $25 \times 50$ & $8 \Phi 12$ & $25 \times 50$ & $8 \Phi 12$ & $6 \varnothing 8$ & Interior \\
\hline Col. 2 & $25 \times 40$ & $6 \Phi 12$ & $25 \times 40$ & $6 \Phi 12$ & $6 \varnothing 8$ & External \\
\hline
\end{tabular}

Table (5) Beams dimensions and reinforcements for building (II)

\begin{tabular}{|c|c|c|c|c|}
\hline \multirow{2}{*}{ Model } & \multirow{2}{*}{ Sec. $(\mathbf{c m})$} & \multicolumn{2}{|c|}{ Reinforcement } & \multirow{2}{*}{$\begin{array}{c}\text { Stirrups } \\
\text { /m }\end{array}$} \\
\cline { 3 - 4 } & & Bottom & Top & $7 \varnothing 8$ \\
\hline B1 & $12 \times 55$ & $2 \Phi 12$ & $2 \Phi 12$ & $7 \varnothing 8$ \\
\hline B2 & $25 \times 55$ & $3 \Phi 12$ & $3 \Phi 12$ & $7 \varnothing 8$ \\
\hline B3 & $20 \times 70$ & $4 \Phi 16$ & $4 \Phi 16$ & 76 \\
\hline
\end{tabular}

\section{Numerical Modelling and Results}

As shown in Figure 11, 3-D models for buildings (I, II) were built to carry out linear structure analysis considering seismic loads using response spectra concept. The analysis was performed using SAP2000 program ver. 20. The Finite Element modelling for each building consists of Frame elements for the columns and beams, whereas the flooring slabs are modelled using Shell elements considering the same dimensions collected through performed field work surveying. The flooring 
slabs are modelled using Diaphragm Constraint for each floor level. The external columns only were checked and the results for buildings (I) and (II) are summarized in Tables 6, 7 respectively.

Building (I)
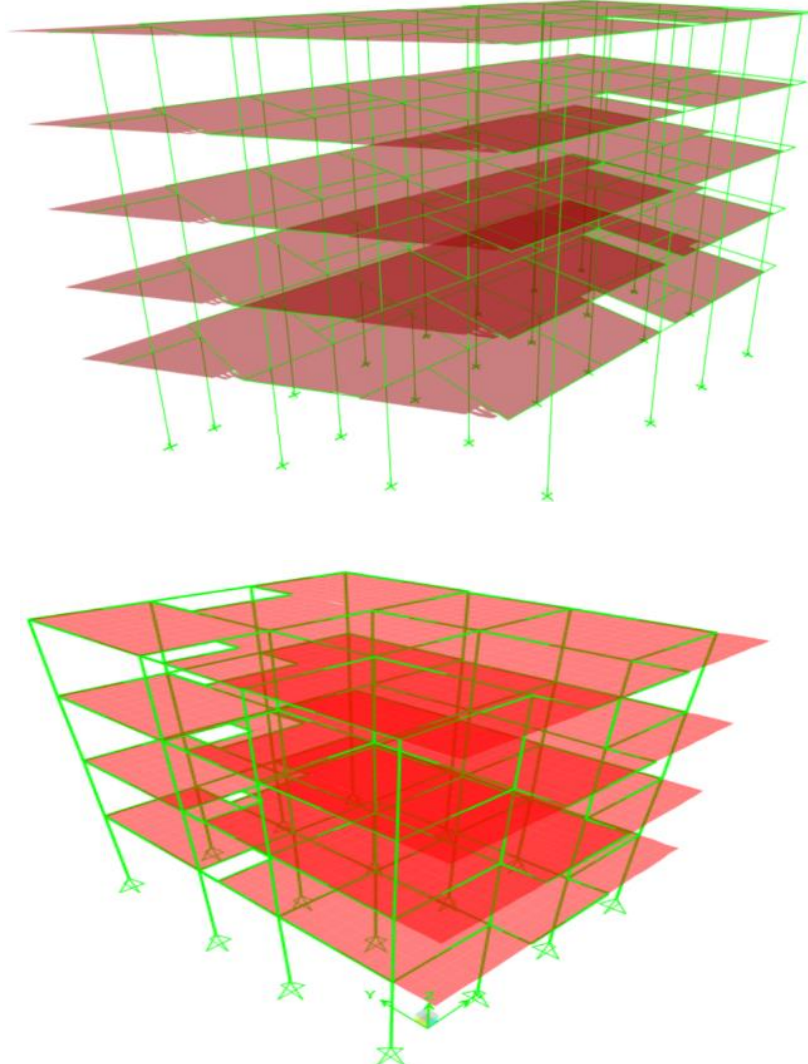

Building (II)

Fig 11 3-D Numerical model for buildings (I, II)

The materials properties are as follows: -

\begin{tabular}{|l|c|c|}
\hline \multicolumn{2}{|c|}{ Concrete } & Steel Reinforcement: \\
\hline Density $=2.5$ & Modulus of Elasticity $=210 \mathrm{t} / \mathrm{cm}^{2}$ & \multirow{2}{*}{ Yield Strength $=3600 \mathrm{~kg} / \mathrm{cm}^{2}$} \\
\hline Poison's Ratio $=0.3$ & Ultimate Strength $=250 \mathrm{~kg} / \mathrm{cm}^{2}$ & \\
\hline
\end{tabular}

*Table (6) External columns results for building (I)

\begin{tabular}{|c|c|c|c|c|c|c|c|}
\hline \multirow{2}{*}{ \# } & \multicolumn{4}{|c|}{ Col. Load } & \multirow{2}{*}{$\begin{array}{l}\text { Col. Dim. } \\
\text { (cm) }\end{array}$} & \multirow{2}{*}{$\begin{array}{l}\text { Col. Ult. } \\
\text { Capacity }\end{array}$} & \multirow{2}{*}{ Status } \\
\hline & $\mathbf{P}_{\mathbf{u}}(\mathbf{t})$ & $\mathbf{P s}_{\mathbf{u}}$ & $\mathbf{P s}_{\mathbf{w}}$ & $\mathbf{P u}$ total & & & \\
\hline C 1 & 124.0 & 14.4 & 10.3 & 138.4 & $30 \times 50$ & 160 & safe \\
\hline C 2 & 112.0 & 17.3 & 12.4 & 129.3 & $30 \times 50$ & 160 & safe \\
\hline C 3 & 96.9 & 16.8 & 12.0 & 113.7 & $25 \times 40$ & 103 & unsafe \\
\hline C 4 & 76.1 & 20.5 & 14.6 & 96.6 & $25 \times 40$ & 103 & safe \\
\hline C 7 & 113.4 & 25.5 & 18.2 & 138.9 & $30 \times 50$ & 160 & safe \\
\hline C10 & 88.8 & 22.0 & 15.7 & 110.8 & $25 \times 40$ & 103 & unsafe \\
\hline $\mathrm{C} 11$ & 100.5 & 42.6 & 30.4 & 143.1 & $30 \times 50$ & 160 & safe \\
\hline C16 & 83.8 & 14.9 & 10.6 & 98.7 & $25 \times 40$ & 103 & safe \\
\hline C18 & 140.6 & 27.7 & 19.8 & 168.3 & $30 \times 50$ & 160 & unsafe \\
\hline C19 & 145.6 & 22.0 & 15.7 & 167.6 & $30 \times 50$ & 160 & unsafe \\
\hline $\mathrm{C} 20$ & 74.5 & 49.1 & 35.1 & 123.6 & $25 \times 40$ & 103 & unsafe \\
\hline $\mathrm{C} 21$ & 95.4 & 45.2 & 32.3 & 140.6 & $30 \times 50$ & 160 & safe \\
\hline $\mathrm{C} 22$ & 129.9 & 28.7 & 20.5 & 158.6 & $30 \times 50$ & 160 & safe \\
\hline $\mathrm{C} 23$ & 80.8 & 26.9 & 19.2 & 107.7 & $30 \times 50$ & 160 & safe \\
\hline $\mathrm{C} 24$ & 130.7 & 34.5 & 24.6 & 165.2 & $30 \times 50$ & 160 & unsafe \\
\hline $\mathrm{C} 25$ & 131.2 & 33.3 & 23.8 & 164.5 & $30 \times 50$ & 160 & unsafe \\
\hline
\end{tabular}

${ }^{*}$ The results are performed considering the axial loads only 
${ }^{*}$ Table (7) External columns results for building (II)

\begin{tabular}{|c|c|c|c|c|c|c|c|}
\hline \multirow{2}{*}{ \# } & \multicolumn{4}{|c|}{ Col. Load } & \multirow{2}{*}{$\begin{array}{c}\text { Col. Dim. } \\
\text { (cm) }\end{array}$} & \multirow{2}{*}{$\begin{array}{l}\text { Col. Ult. } \\
\text { Capacity }\end{array}$} & \multirow{2}{*}{ Status } \\
\hline & $P_{u}(t)$ & $\mathbf{P s}_{\mathbf{u}}$ & $\mathbf{P S}_{\mathbf{w}}$ & $\mathbf{P u}$ total & & & \\
\hline $\mathrm{C} 1$ & 56.7 & 30.7 & 21.9 & 87.4 & $25 \times 40$ & 103 & safe \\
\hline $\mathrm{C} 2$ & 93.0 & 23.9 & 17.1 & 116.9 & $25 \times 40$ & 103 & unsafe \\
\hline $\mathrm{C} 3$ & 95.0 & 18.5 & 13.2 & 113.5 & $25 \times 40$ & 103 & unsafe \\
\hline C4 & 60.6 & 27.1 & 19.4 & 87.7 & $25 \times 40$ & 103 & safe \\
\hline $\mathrm{C} 5$ & 69.2 & 25.4 & 18.1 & 94.6 & $25 \times 40$ & 103 & safe \\
\hline C8 & 72.1 & 23.5 & 16.8 & 95.6 & $25 \times 40$ & 103 & safe \\
\hline C9 & 85.8 & 27.9 & 19.9 & 113.7 & $25 \times 50$ & 131 & safe \\
\hline $\mathrm{C} 12$ & 83.4 & 23.0 & 16.4 & 106.4 & $25 \times 40$ & 103 & unsafe \\
\hline $\mathrm{C} 13$ & 50.2 & 29.7 & 21.2 & 79.9 & $25 \times 40$ & 103 & safe \\
\hline $\mathrm{C} 14$ & 75.4 & 15.8 & 11.3 & 91.2 & $25 \times 40$ & 103 & safe \\
\hline $\mathrm{C} 15$ & 70.8 & 13.7 & 9.8 & 84.5 & $25 \times 40$ & 103 & safe \\
\hline $\mathrm{C} 16$ & 53.7 & 24.9 & 17.8 & 78.6 & $25 \times 40$ & 103 & safe \\
\hline
\end{tabular}

${ }^{*}$ The results are performed considering the axial loads only

were.

* $\mathrm{P}_{\mathrm{u}}$ : Ultimate Gravity Column Load - * $\mathrm{Ps}_{\mathrm{u}}, \mathrm{Ps}_{\mathrm{w}}$ : Ultimate and Working Seismic Column Load respectively

* Putotal: Total Ultimate Column Load - * Add. Seismic load = Max. of: $(\mathrm{Ex}+0.3$ Ey) or $(\mathrm{Ey}+0.3$ Ex)

* For both buildings (I, II), the seismic loading was applied in both short and long directions, and the maximum results were considered.

As indicated, all columns for the two studied buildings (I, II) have been proven to be safe under the effect of gravity loadings. Whereas, considering the effect of additional seismic loads, for building (I), 7 external columns are unsafe, while for building (II), only 3 external columns are unsafe. The interpretation of this result is due to the irregularity of building (I). Thus, the torsional effect is more effective which leads to increasing the resulting seismic effect compared to building (II). Besides, basically the impacts of earthquake loads were not considered completely for these non-engineering constructions. Applying the proposed formula for estimating the additional seismic load to the studied buildings (I, II), and comparing with the results of the numerical modelling, it is concluded that: For building $(\mathrm{I}): \mathrm{h}=16 \mathrm{~m}$, thus; the additional seismic load for an exterior column $\triangle P$ equals:

$$
\Delta P=\left(\frac{h^{2}}{10}\right)=25.6 \mathrm{t}
$$

as shown in Table (6) and Figure (12-a), comparing this value to the average analytical seismic loads for external columns indicates a difference about $8 \%$. Whereas, for building (II): $\mathrm{h}=13 \mathrm{~m}$, thus; the additional seismic load for an exterior column $\triangle P$ equals:

$$
\Delta P=\left(\frac{h^{2}}{10}\right)=16.9 \mathrm{t},
$$

as shown in Table (7) and Figure (12-b), this value is nearly equal to the average value of the calculated seismic loads for the exterior columns. It is obvious that the application of the proposed formula for building (II) is more convenient due to its regularity compared to building (I). 


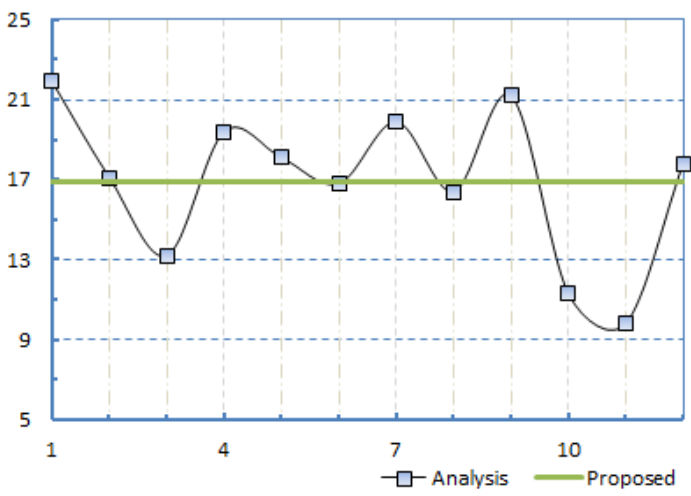

a. Building (I)

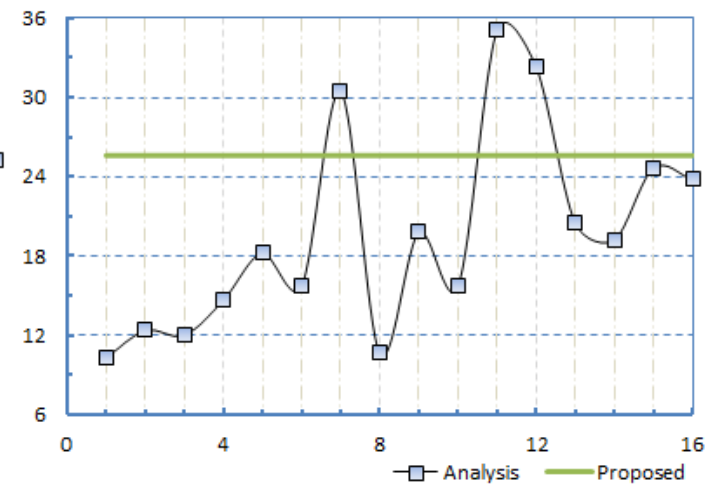

b. Building (II)

Fig 12 Comparison of seismic load between analytical and proposed formula

Furthermore, for building (I), the deviation of the proposed formula seismic load related to the lower and higher numerical seismic columns' loads ranges between $-44 \%$ and $+92 \%$. Whereas, for building (II), it ranges between $-42 \%$ and $+30 \%$.

\section{Conclusions}

This study leads to the following conclusions:

- The suggested method can be used to estimate the seismic effect on buildings with 4-7 floors in simple and easy ways with an acceptable approximation.

- The proposed method can quickly classify the buildings with the highest degree of danger or not, and the buildings that need a more detailed study.

- The application of the proposed method is more convenient for regular configuration buildings.

- This study could be used to establish controls to re-planning or to issue regulations on the buildings of existing slum areas to ensure the minimum safety or at least reduce the risk of collapses in the event of moderate earthquakes.

Further studies should consider the effect of pounding, which is the most common situation in the countryside and slums, and whether this affects positively or negatively the safety of buildings.

\section{References}

1. Abdo, A.M., Hamada, R.M., "Journal of Al Azar University Engineering Sector, October 2017, 1615-11626.

2. Badawy, A., Gaber, H., Ibrahim, H. "Earthquake Risk Assessment of Alexandria, Egypt". Journal of Seismology, 2016; DOI 10.1007/s10950-014-9456-x, January 2015.

3. Charlotte Malterre-Barthes, "Housing Cairo from Small-Scale Informal Housing Construction to Semi-Professional Speculative Urban Schemes" Low/No Cost Housing Conference, Zurich, Swizerland, June 2016.

4. Chopra, K., Anil, "Dynamics of Structures", Prentice Hall, Englewood Cliffs, New Jersey, 1995.

5. El-Betar, S.A., 2016. "Seismic Vulnerability Evaluation of Existing R.C. Buildings", HBRC Journal, 2016. DOI: 10.1016/j.hbrcj.2016.09.002.

6. Fahmy, Y.G.M., Abd-Elfattah, H.H. "Assessment of Existing Non-Engineered Residential Building in Rural Area Based on Egyptian Code of Practice" Al-Azhar University Civil Engineering Research Magazine (CERM) Vol. (40) No. (1) January 2018.

7. Hashad, A., "Methodology to Estimate Bending Stresses Due to Vibration of Simple Beams" The NWRC international conference "Research and technology development for sustainable water resources management" Cairo, December 2016.

8. "SAP2000 Nonlinear Ver. 20”, Computers and Structures, Inc., Berkeley, California, USA, 2002. 
9. Sobaih, M.E., Nazif, M.A. "A Proposed Methodology for Seismic Risk Evaluation of Existing Reinforced School Buildings" HBRC Journal, April 2012, https://doi.org/10.1016/j.hbrcj.2012.10.006.

10. The Egyptian Code for Loads and Forces in Construction and Building Works, -201", Housing and Building Research Center, Giza, Egypt, 2012.

11. "The Egyptian Code for Design and Construction of Concrete Structures-203", Housing and Building Research Center, Giza, Egypt, 2017.

\section{مقترح لضوابط استرشادية لتقييم أحمال الزلازل على المبانى بالمناطق العشوائية}

ملخص البحث

تنتشر العثوائيات و المباني غير المصممة طبقا للاعتبار ات والمتطلبات الهندسية المعتمدة في معظم أنحاء ومحافظات مصر. و هذه المبانى لم يراعى في تصميمها أو تتفيذها اتباع مواصفات و اشتر اطات الكودات المصرية للتصميم والانشاء، مما يؤدى بالتبعية الى الريبة وانعدام الموثوقية في مستوى الامان لهذه المنشئات. ويقترح هذا البحث طريقة مبسطة لتحديد مدى الامان ومستوى الخطورة لحالات هذه المبانى وقدرتها على مقاومة أحمال الزلازل. ويركز البحث على الأعمدة الخارجية للمبنى في مقاومة أحمال الزلازل وليس جميع الأعمدة، حيث هي الأكثر تعرضا لأحمال الز لازل خاصة لنمط المبانى محل الدراسة والتي في الغالب الأعم ال تشتمل على أنظمة انثائية لمقاومة القوى العرضية. كذلك تم التركيز في البحث على تأثير قوى الزلازل على الى الأحمال الر أسية فقط .وقد تمت دراسة مدى صالحية الطريقة المقترحة تجريبيا وتحليليا، بينما تم اختبار نتائج تطبيقها بأجر اء در اسة حقلية لعدد r مبنى قائم تتسم بنفس مواصفات المبانى محل الدر اسة، وذلك بعمل تحليل إنشائي فر اغي متكامل لها لتحديد مدى كفاءة الطريقة المقترحة بالمقارنة مع نتائج التحليل الإنشائي الدقيق. وقد روعي في اختيار المبانى المطبق عليها الدر اسة أ تمثل نماذج فعلية مناظرة للمباني شائعة الاستخدام في أنحاء القطر المصري من حيث المساحة وعدد الأدوار، وتقع هذه المبانى في احدى قرى الريف المصري بمحافظة الثرقية. وقد تم اجراء المعاينة وأعمال الرفع الهندسي لكافة العناصر الإنشائية للمباني، ثم تم عمل نماذج رياضية فر اغية للمباني المطبق عليها الدراسة الجراء التحليل الإنشائي ودراسة تأثنر اضافة أحمال الزلازل عليها .و تقدم الدر اسة استنباط لصياغة رياضية مبسطة لتقييم مستوى المخاطر التي تتعرض لها المبانى بالمناطق العشو ائية و الغير مصممة وفق الأصول والاشتر اطات الهندسية. كما يمكن استخدام هذه الصياغة لوضع ضوابط العادة التخطبط أو التقنين لتلك المنشئات بما يحقق الحد الأدنى للأمان أو على الأقل التقليل من أخطار الانهيار ات في حالات الزلازل المتوسطة الثدة .

الكلمات الدالة: التحليل الديناميكي ـ تقييم حالة المبنى ـ التصميم الزلز الي ـ تقييم مستوى المخاطر 